\title{
Palaeoecological records of coral community development on a turbid, nearshore reef complex: baselines for assessing ecological change
}

\author{
J. A. Johnson ${ }^{1}$ - C. T. Perry ${ }^{1}$ - S. G. Smithers ${ }^{2}$ - K. M. Morgan $^{1}$ - N. Santodomingo ${ }^{3}$ ' \\ K. G. Johnson ${ }^{3}$
}

Received: 21 September 2016/ Accepted: 5 January 2017/Published online: 4 March 2017

(C) The Author(s) 2017. This article is published with open access at Springerlink.com

\begin{abstract}
Understanding past coral community development and reef growth is crucial for placing contemporary ecological and environmental change within appropriate reef-building timescales. On Australia's Great Barrier Reef (GBR), coral reefs situated within coastal inner-shelf zones are a particular priority. This is due to their close proximity to river point sources, and therefore susceptibility to reduced water quality discharged from coastal catchments, many of which have been modified following European settlement (ca. $1850 \mathrm{AD}$ ). However, the extent of waterquality decline and its impacts on the GBR's inner-shelf reefs remain contentious. In this study, palaeoecological coral assemblage records were developed for five proximal coral reefs situated within a nearshore turbid-zone reef complex on the central GBR. A total of 29 genera of Scleractinia were identified from the palaeoecological inventory of the reef complex, with key contributions to reef-building made by Acropora, Montipora, and Turbinaria. Discrete intervals pre- and post-dating European settlement, but associated with equivalent water
\end{abstract}

Communicated by Geology Editor Prof. Eberhard Gischler

Electronic supplementary material The online version of this article (doi:10.1007/s00338-017-1561-1) contains supplementary material, which is available to authorized users.

J. A. Johnson

jj304@exeter.ac.uk

1 School of Geography, College of Life and Environmental Sciences, University of Exeter, Exeter EX4 4RJ, UK

2 College of Marine and Environmental Sciences, James Cook University, Townsville, QLD 4811, Australia

3 Department of Palaeontology, Natural History Museum, Cromwell Road, London SW7 5BD, UK depths, were identified using Bayesian age-depth modelling, enabling investigation of competing ideas of the main drivers of nearshore coral assemblage change. Specifically, we tested the hypotheses that changes in the composition of nearshore coral assemblages are: (1) intrinsically driven and linked to vertical reef development towards sea level, and (2) the result of changes in water quality associated with coastal river catchment modification. Our records found no discernible evidence of change in the generic composition of coral assemblages relative to European settlement. Instead, two distinctive depth-stratified assemblages were identified. This study demonstrates the robust nature of nearshore coral communities under reported water-quality decline and provides a useful context for the monitoring and assessment of ecological change on reefs located within the most nearshore turbidzone environments of the central GBR.

Keywords Ecological baselines - European settlement . Great Barrier Reef · Inner shelf · Palaeoecology · Water quality

\section{Introduction}

Nearshore coastal environments that experience high levels of sedimentation and turbidity are widely perceived as 'marginal' (sensu Perry and Larcombe 2003) for coral growth and reef development. This is because sediments, especially fine-grained terrigenous sediments, can reduce coral fecundity and survival (Erftemeijer et al. 2012; Jones et al. 2015). Coral reefs located in environments exposed to regimes of naturally high sediment flux (defined by the total mass of sediment deposited and resuspended; Browne et al. 2012c) are often referred to as 'turbid-zone reefs'. On 
Australia's Great Barrier Reef (GBR), turbid-zone reefs occur across a range of geomorphic settings, located within a shallow ( $<20 \mathrm{~m}$ deep) inner-shelf zone which extends up to $20 \mathrm{~km}$ offshore of the mainland coast (Larcombe and Woolfe 1999b; Browne et al. 2012a). The inner shelf of the GBR is characterised by the presence of fine-grained terrigenous sediments which form an inshore sediment prism that extends offshore towards a seaward limit close to the 15-m isobath (Woolfe and Larcombe 1999). In the shallow $(<5 \mathrm{~m}$ depth) coastal areas of the inner shelf, these finegrained sediments are frequently resuspended by waves, producing wide fluctuations in turbidity (Larcombe et al. 2001; Browne et al. 2012b). Based on the prevailing environmental conditions, a distinction has recently been made between inner-shelf reefs that occur within coastal 'nearshore' ( $<10 \mathrm{~m}$ isobath) areas and those located further offshore in more 'inshore' settings ( $>10 \mathrm{~m}$ isobath), where the local natural sedimentary background conditions are less extreme (Morgan et al. 2016a).

Despite the sedimentary setting of the GBR inner shelf, the reefs located within this zone can support diverse coral communities. Regional species richness typically exceeds 60 species across the entire inner shelf (Sweatman et al. 2007) and live coral cover averages $\sim 20 \%$ (www.aims. gov.au/docs/data-centre/reef-monitoring-surveys.html), but can be as high as $\sim 40 \%$ (e.g. Browne et al. 2010; Morgan et al. 2016a). However, declining water quality is considered a major threat to the health of inner-shelf reefs across the GBR (Brodie et al. 2012). Since European settlement (ca. $1850 \mathrm{AD}$ ), the annual input of sediment into the GBR lagoon is estimated to have increased by a factor of 5.5, while inputs of nitrogen and phosphorus are estimated to have increased by approximately six- and ninefold, respectively (Lewis et al. 2007; Kroon et al. 2012). In spite of these reported increases in sediment and nutrient loads, the impact of declining water quality on the GBR's innershelf reefs remains contested. Central to the debate is uncertainty related to the impact of increased sediment loads relative to the natural movement and resuspension of sediments which have accumulated on, and characterised, the inner shelf over the last $\sim 6000 \mathrm{yr}$ (Larcombe and Woolfe 1999b).

Divergent ecological trajectories further confound the issue, with some studies reporting long-term coral community stability under the continuous influence of terrigenous sediments (Perry et al. 2008, 2009; Roche et al. 2011; Ryan et al. 2016), while others have linked shifts in coral assemblages to anthropogenically induced water-quality decline (e.g. Fabricius et al. 2005; Roff et al. 2013). One explanation for the apparent disparity between existing ecological records is that the impact of increasing sediment influx is spatially heterogeneous, with an emerging hypothesis that nearshore coral communities are pre- adapted to, and thus better able to cope with, conditions of low light availability and sedimentation (Perry et al. 2008; Morgan et al. 2016a; Ryan et al. 2016). This pre-adaption may therefore have instilled a greater resilience within these nearshore coral communities to changes in water quality than those of inshore reefs, which are located further offshore towards the inner/mid-shelf boundary, and where the influence of suspended sediments and the frequency of exposure to river flood plume-associated particulates (i.e. nutrients and solids) is lower (Devlin and Brodie 2005; Perry et al. 2008; Morgan et al. 2016a).

On the GBR, palaeoecological investigations have provided valuable insights into the regional controls and longterm reef development of the most nearshore coral communities (see Browne et al. 2012a for review). An important concept to emerge from these studies is that changes in nearshore coral assemblages are intrinsically driven and related to shallowing environmental conditions during vertical reef development towards sea level (e.g. Perry et al. 2008, 2009; Roche et al. 2011; Ryan et al. 2016). To date, however, studies of nearshore coral assemblage changes, over appropriate reef-building timescales (i.e. $>$ decadal), have largely been restricted to individual reefs that have attained sea level (i.e. reefs within the late stages of 'geomorphological maturity' sensu Hopley 1982). Here, we use a core-based approach to develop detailed palaeoecological coral assemblage records for five proximal nearshore reefs presently existing at different stages of geomorphological development. Established palaeoecological records were used to test competing ideas of the main drivers of nearshore coral assemblage change within the central GBR. Specifically, we test the hypotheses that changes in the composition of nearshore coral assemblages are: (1) intrinsically driven and linked to vertical reef development towards sea level, and (2) the result of changes in water quality associated with coastal river catchment modification following European settlement.

\section{Materials and methods}

\section{Study site}

The Paluma Shoals reef complex (PSRC) comprises seven nearshore coral reefs distributed across an area of $\sim 16 \mathrm{~km}^{2}$, located in Halifax Bay on the central GBR (Fig. 1; Morgan et al. 2016a). With the exception of Paluma Shoals (north shoal), the reefs of the PSRC are detached from the mainland and extend up to $3 \mathrm{~km}$ offshore. Presently, the reefs of the PSRC are at various stages of geomorphological development (see Morgan et al. 2016a, b; Fig. 1) ranging from: (1) the fully submerged reef structures of Offshore Paluma Shoals A, B, C, and D 
Fig. 1 Site maps showing the location of a Halifax Bay, Queensland, Australia; b the Paluma Shoals Reef Complex (PSRC) in Halifax Bay, central Great Barrier Reef (red box); and $\mathbf{c}$ an aerial image of the PSRC and its constituent reefs: Paluma Shoals (north and south shoal), Offshore Paluma Shoals (OPS), Offshore Paluma Shoals A, B, C and D (OPS-A, B, C and $\mathrm{D})$. The presented isobath contours are in metres and are derived from Beaman (2010)
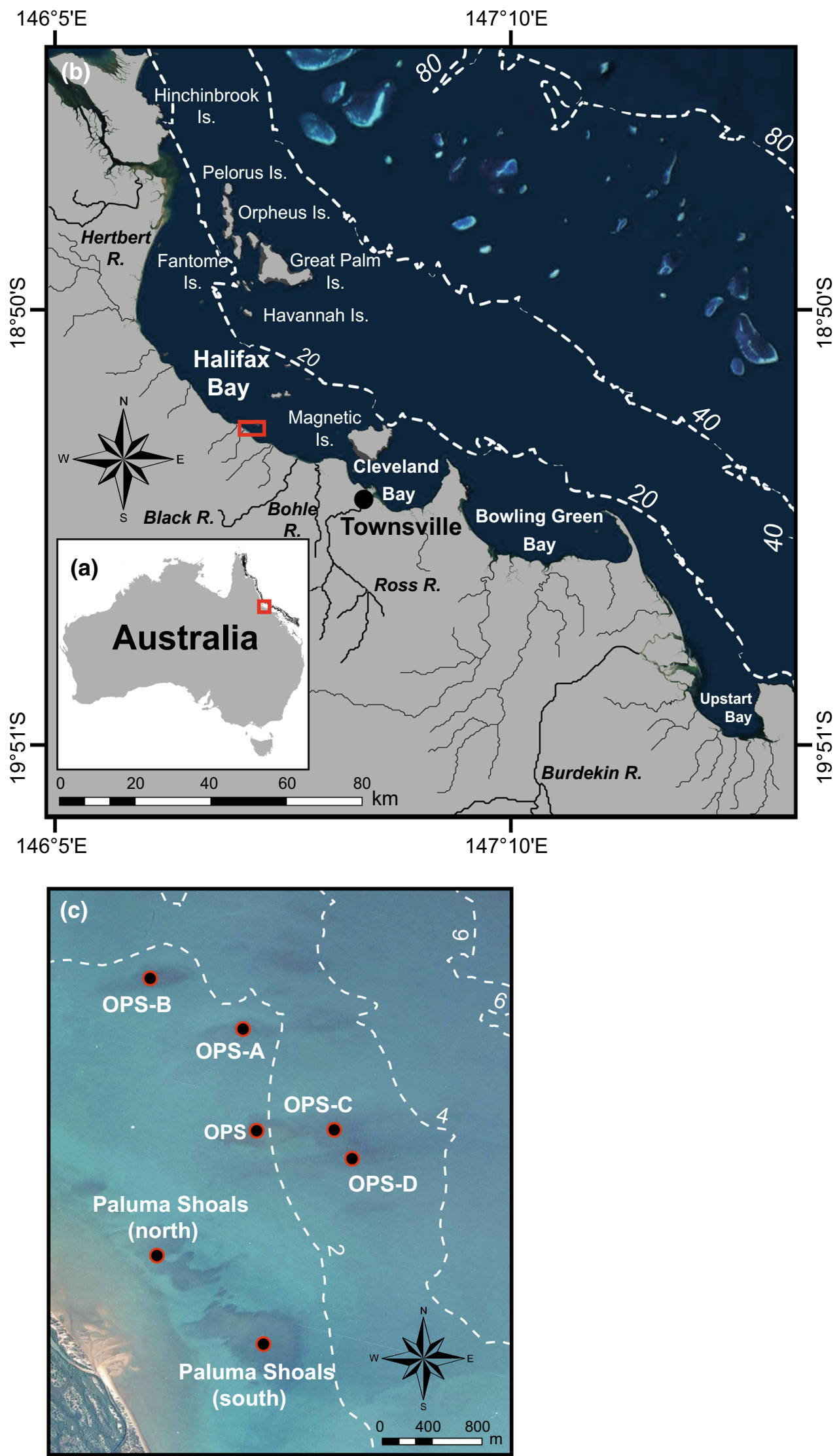
(OPS-A, B, C, and D); (2) the reef structure of Offshore Paluma Shoals (OPS) that is emergent at lowest astronomical tide (LAT); and (3) Paluma Shoals (north and south shoal) that have attained sea level.

Halifax Bay is a shallow ( $<20 \mathrm{~m}$ water depth), low-gradient ( $<1: 1000)$ embayment, with a semi-diurnal tidal cycle and a spring tide maximum of $3.8 \mathrm{~m}$ (Larcombe et al. 2001). In the PSRC, water turbidity is strongly influenced by wave activity, with suspended sediment concentrations increasing (>200 $\mathrm{mg} \mathrm{L}^{-1}$ ) following exposure to larger waves $\left(\mathrm{H}_{\mathrm{s}}>0.5 \mathrm{~m}\right)$ generated by persistent winds (Browne et al. 2012b). On Paluma Shoals, average sedimentation rates vary among geomorphological zones, ranging from $0.9 \mathrm{~g} \mathrm{~m}^{-2}$ $\mathrm{d}^{-1}$ on the reef flat to $120 \mathrm{~g} \mathrm{~m}^{-2} \mathrm{~d}^{-1}$ in more sheltered leeward locations (Browne et al. 2012c).

\section{Core recovery}

To reconstruct palaeoecological coral assemblages from the PSRC, 16 percussion cores (method described in Smithers and Larcombe 2003) were recovered across four separate reefs (OPS-A, B, C and D; Fig. 1) during the 2013 and 2014 winter (July), spring low-tide windows, using 95-mm-internal-diameter aluminium piping (Fig. 2). Core records were augmented by an additional five cores previously recovered from OPS in July 2010 (see Perry et al. 2013) and which have not previously been used for palaeoecological analysis. Water depth and time of measurement were recorded at each core location, allowing core elevations to be reduced to LAT. Core recovery was $100 \%$ in all cases, with an average penetration of approximately $4 \mathrm{~m}$ (Table 1). Importantly, all but four cores terminated in pre-reefal sedimentary sequences of lithic sands or stiff mottled clays (Fig. 2). Core compaction, calculated (assuming uniform compaction) using core length and penetration measurements, was variable and ranged from 21 to $52 \%$ (Table 1). Following collection, cores were split, photographed and logged (Fig. 2).

\section{Taxonomic analysis}

To determine the abundance of coral taxa, and to enable comparison of coral assemblages at equivalent water depths, all cores were divided into continuous 40-cm (uncompacted) intervals, relative to LAT. The interval size was selected as a compromise to be large enough to be ecologically meaningful (i.e. to adequately represent coral life assemblages), but small enough to obtain a sufficient number of samples from each core. Initially, each sample interval was wet-sieved to separate the fine-grained $(<0.063 \mathrm{~mm})$ and sand-sized $(<2 \mathrm{~mm})$ sediments from the coarser clastic materials. The retained materials $(>2 \mathrm{~mm})$ were then oven-dried before sieving (sieve aperture:
$10 \mathrm{~mm}$ ) to isolate individual coral clasts. For identification, collected clasts were grouped according to visible morphological traits, including: (1) overall growth morphology; (2) corallite arrangement and budding; (3) corallite morphology; and (4) coenosteum and internal corallite structure.

Over 18,000 individual coral clasts $(\sim 85 \mathrm{~kg}$ of coral material) were recovered and identified from the 21 cores. To ensure taxonomic consistency within this study, and to enable reliable comparisons to be made with previous investigations, corals were identified to genus. In order to build a palaeoecological species inventory for the PSRC, more detailed species-level taxonomic analyses were conducted on collected type specimens. Specimen identification followed Veron and Pichon (1976, 1980, 1984), and Cairns and Parker (1992), while corals of the genus Acropora followed descriptions by Wallace (1999). Species names and their spatial distributions were validated using online databases provided by the World Registry of Marine Species (WoRMS; www.marinespecies.org/) and the Ocean Biogeographic Information System (OBIS; www.iobis.org).

Overall, coral materials exhibited a high degree of preservation. Approximately $10 \%$ of the examined coral clasts were indeterminate and classified as 'unidentified'. Generic abundances were determined by the relative contribution of each taxon to the total mass of identified coral within each sample interval. This method provides a good representation of fossil coral assemblage composition as it reduces the influence of preferential preservation which biases frequency-based abundance estimates towards corals with more fragile growth forms (i.e. branching and platy corals; Edinger et al. 2001; Santodomingo et al. 2016).

\section{Statistical analysis}

\section{Taxonomic richness}

To assess the extent to which the sampling strategy captured the taxonomic richness of each reef, sample-based rarefaction analysis was conducted in EstimateS (version 9.1; Colwell 2013). The analysis followed methods described in Colwell et al. (2012), enabling the production of both rarefaction and extrapolation curves, together with their associated confidence intervals. To produce smooth curves, the analysis followed recommendations in Colwell (2013). Individual cores were treated as samples and randomised (resampled) 100 times, while curve extrapolations were conducted to twice the sample reference number.

\section{Coral assemblages}

Prior to further statistical analyses, 'rare' taxa (those accounting for $<0.5 \%$ of the total mass of identified coral 


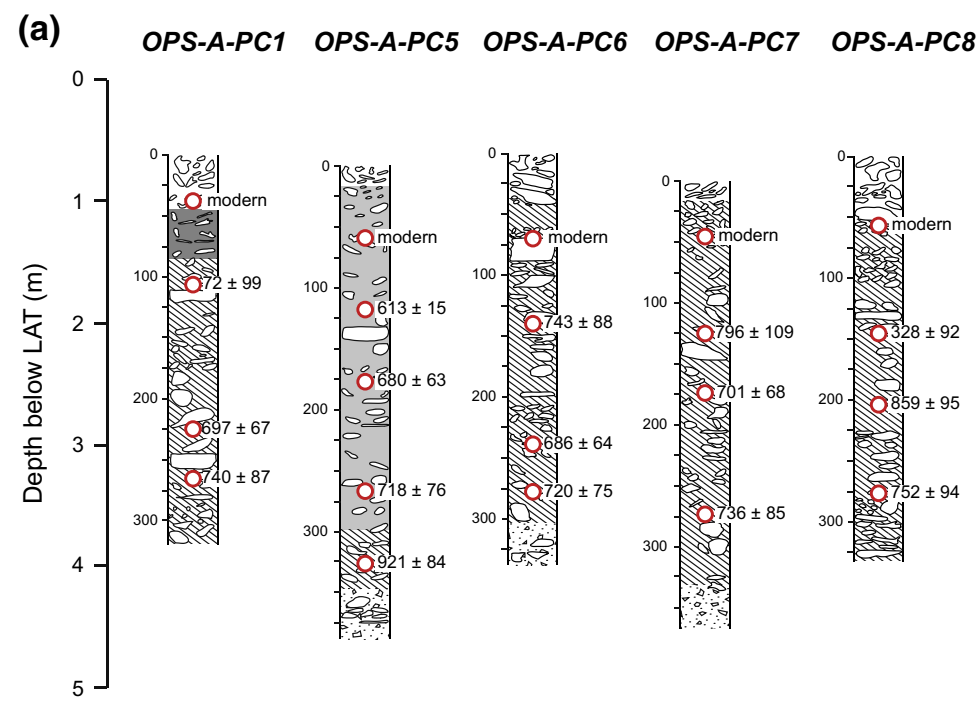

(b)

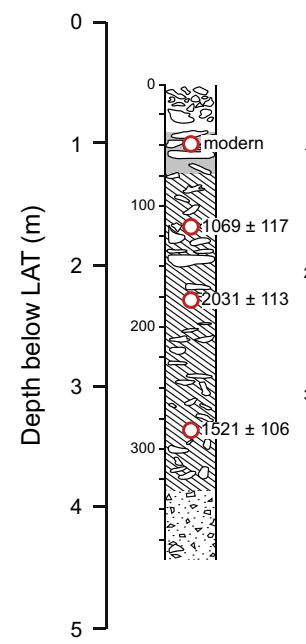

OPS-B-PC1 OPS-B-PC3 OPS-B-PC4 OPS-B-PC5 OPS-B-PC6

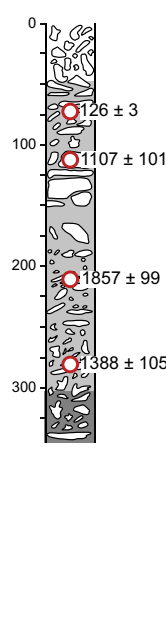

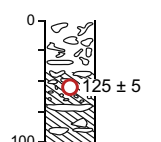
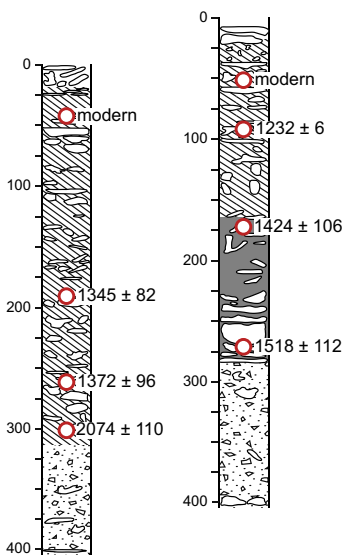

(c) OPS-C-PC1 OPS-C-PC2 OPS-C-PC3

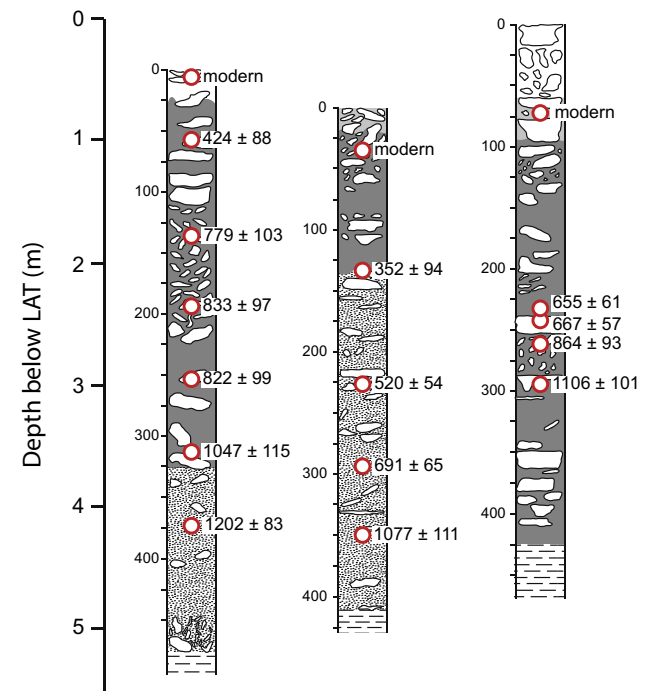

(d)

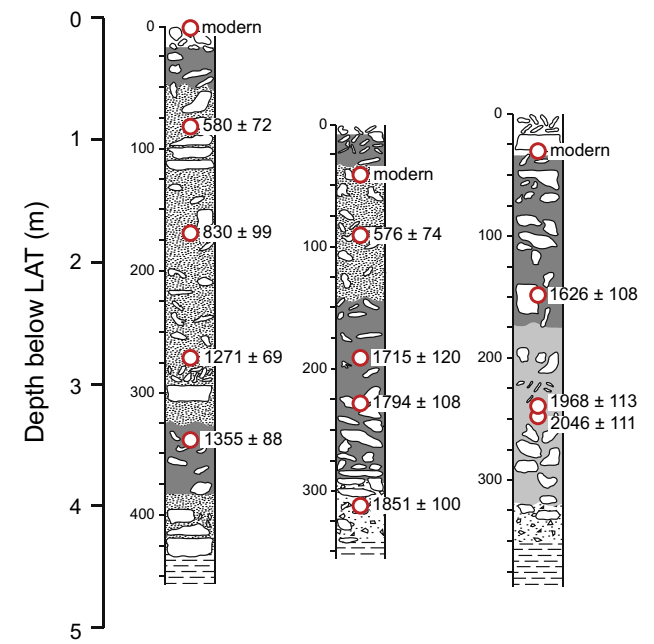

\section{Facies Key:}

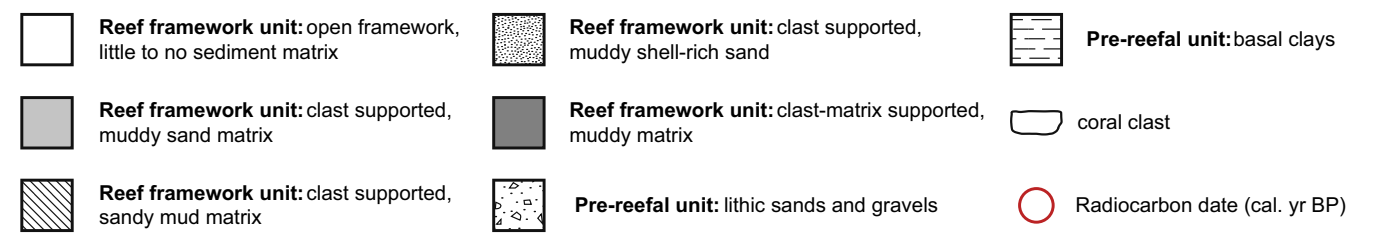

Fig. 2 Stratigraphic diagrams and chronostratigraphies of the cores recovered from a Offshore Paluma Shoals (OPS)-A; b OPS-B; $\mathbf{c}$ OPS$\mathrm{C}$; and d OPS-D. All core depths ( $\mathrm{cm}$ ) have been uncompacted and are presented relative to lowest astronomical tide. The median

material) were excluded, following recommendations in Clarke and Warwick (2001) and based on the assertion that their abundance, as represented within fossil records, can be unreliable for statistical comparison (Bonelli et al. probability ages of the available radiocarbon dates (Morgan et al. 2016b) are presented in calibrated years before present (cal. yr $\mathrm{BP} \pm 1 \sigma$ ). The term 'modern' denotes ages associated with dates post-dating $1950 \mathrm{AD}(0 \mathrm{cal}$. yr BP)

2006). The identified 'rare' taxa included 13 genera, equating to approximately 400 clasts. Cumulatively, the 'rare' taxa accounted for less than $3 \%$ of the total mass of examined coral materials (Table 2). Only depth intervals 
Table 1 Details of percussion cores collected from the Paluma Shoals Reef Complex

\begin{tabular}{|c|c|c|c|c|c|}
\hline Reef & Core & $\begin{array}{l}\text { Depth relative } \\
\text { to LAT }(\mathrm{m})\end{array}$ & $\begin{array}{l}\text { Core } \\
\text { length (m) }\end{array}$ & $\begin{array}{l}\text { Penetration } \\
\text { (m) }\end{array}$ & $\begin{array}{l}\text { Compaction } \\
(\%)\end{array}$ \\
\hline \multirow[t]{5}{*}{ OPS-A } & PC-1 & -0.63 & 2.2 & 3.0 & 32 \\
\hline & PC-5 & -0.75 & 2.9 & 3.8 & 25 \\
\hline & PC-6 & -0.70 & 2.6 & 3.8 & 32 \\
\hline & PC-7 & -0.86 & 2.5 & 3.8 & 32 \\
\hline & PC-8 & -0.66 & 1.9 & 3.4 & 43 \\
\hline \multirow[t]{5}{*}{ OPS-B } & PC-1 & -0.52 & 2.6 & 4.0 & 35 \\
\hline & PC-3 & -0.90 & 1.9 & 3.3 & 42 \\
\hline & PC-4 & -0.45 & 2.4 & 4.0 & 41 \\
\hline & PC-5 & -0.66 & 2.7 & 3.9 & 33 \\
\hline & PC-6 & -0.29 & 2.8 & 4.1 & 33 \\
\hline \multirow[t]{3}{*}{ OPS-C } & PC-1 & -0.41 & 2.8 & 5.0 & 44 \\
\hline & PC-2 & -0.73 & 2.8 & 4.1 & 34 \\
\hline & PC-3 & -0.50 & 2.6 & 4.6 & 45 \\
\hline \multirow[t]{3}{*}{ OPS-D } & PC-1 & -0.70 & 2.5 & 4.5 & 44 \\
\hline & PC-2 & -0.88 & 2.5 & 3.5 & 28 \\
\hline & PC-3 & -0.80 & 1.8 & 3.8 & 52 \\
\hline \multirow[t]{5}{*}{ OPS } & PC-1 & -0.25 & 3.5 & 4.5 & 21 \\
\hline & PC-2 & -0.18 & 3.0 & 4.0 & 24 \\
\hline & PC-3 & 0.15 & 3.5 & 5.0 & 28 \\
\hline & PC-4 & 0.35 & 3.0 & 4.1 & 32 \\
\hline & PC-5 & -0.15 & 2.6 & 3.7 & 28 \\
\hline
\end{tabular}

with more than two core replicates per reef were included in statistical tests. All abundance data (per cent mass abundance) were fourth-root-transformed to reduce data asymmetry (Legendre and Birks 2012) unless stated otherwise.

A two-way permutational multivariate analysis of variance (PERMANOVA; Anderson 2001) with 9999 permutations was used to characterise the coral assemblages preserved within the palaeoecological record of the PSRC and to investigate variations in assemblage composition among individual reefs and water depth intervals. Pairwise PERMANOVAs with sequential Bonferroni significance tests were conducted by means of post hoc testing to investigate variations in coral assemblage composition between depth intervals, while similarity percentage (SIMPER; Clarke 1993) analysis was used to identify the taxa contributing most to inter-reef dissimilarity. Both PERMANOVA and SIMPER analyses were performed in PAST (version 3; Hammer et al. 2001) using Bray-Curtis measures of dissimilarity.

\section{Species response curves}

The statistical approach described above assumes that changes in coral assemblage composition are independent of age and are a function of water depth. To further investigate the vertical distribution of corals along the water depth gradient, species response curves were produced by generalised additive modelling (GAM) for coral genera for which there were sufficient observations. Models used a cubic smooth spline function with the response variable (relative mass abundance) assigned a quasi-Poisson distribution across all available depth intervals, following recommendations in Lepš and Šmilauer (2003). As the quasi-Poisson distribution uses a canonical log-link function, modelling used untransformed data (Skácelová and Lepš 2014). For each genus, models were compared against the null model at different degrees of complexity (expressed as degrees of freedom; $d f \leq 6$ ). The optimal model (i.e. the one with the highest parsimony) was selected by comparison of computed Akaike information criterion values (Lepš and Šmilauer 2003). Both the production of species response curves and model selection were performed in CANOCO (version 4.5; Ter Braak and Šmilauer 2002).

\section{European settlement}

To test the hypothesis that changes in water quality following European settlement (ca. 1850 AD) have altered the composition of coral communities within the PSRC, agedepth models were produced for each core using a flexible Bayesian approach in the software package 'bacon' (version 2.2; Blaauw and Christen 2011), run in the R statistical 
Table 2 Relative contributions of coral genera to the total mass of identified coral material

\begin{tabular}{|c|c|}
\hline Genus & Contribution (\%) \\
\hline Acropora & 45.7 \\
\hline Montipora & 22.5 \\
\hline Turbinaria & 11.2 \\
\hline Euphyllia & 4.4 \\
\hline Porites & 2.8 \\
\hline Favites & 2.2 \\
\hline Cyphastrea & 1.5 \\
\hline Galaxea & 1.4 \\
\hline Goniopora & 1.3 \\
\hline Hydnophora & 1.0 \\
\hline Fungia & 0.9 \\
\hline Pavona & 0.8 \\
\hline Platygyra & 0.8 \\
\hline Psammocora & 0.7 \\
\hline Pachyseris & 0.6 \\
\hline Alveopora & 0.5 \\
\hline Dipsastraea* & 0.4 \\
\hline Oulophyllia* & 0.4 \\
\hline Stylophora* & 0.4 \\
\hline Duncanopsammia* & 0.2 \\
\hline Lobophyllia* & 0.2 \\
\hline Coscinarea* & 0.1 \\
\hline Echinophyllia* & 0.1 \\
\hline Leptoseris* & 0.1 \\
\hline Oxypora* & 0.1 \\
\hline Balanophyllia* & 0.0 \\
\hline Echinopora* & 0.0 \\
\hline Heterocyathus* & 0.0 \\
\hline Pocillopora* & 0.0 \\
\hline
\end{tabular}

Specimen reference plates are available in ESM Figs. S1-S6

* Denotes genera that were identified as 'rare' $(<0.5 \%$ contribution to the total mass of identified coral)

interface (R Development Core Team 2014). Bayesian approaches are increasingly favoured for chronological reconstructions as they consider both age uncertainty and the distributional probability of all available dates (Bennett 1994; Parnell et al. 2011). In 'bacon', age-depth models are produced by thousands to millions of Markov chain Monte Carlo iterations, constrained by accumulation rates informed by prior model information, which are then reduced to remove any auto-correlation between model runs (Blaauw and Heegaard 2012). Prior model information was informed by previously published rates of vertical reef accretion within nearshore environments on the GBR (see Perry et al. 2012) and followed recommendations for likely variable rates of accumulation (i.e. low model memory; Blaauw and Christen 2011).
The age-depth models used a total of 96 published radiocarbon dates available for the 21 cores recovered across the PSRC (see Perry et al. 2013; Morgan et al. 2016b; Fig. 2). Model outputs provided age estimates at a $1-\mathrm{cm}$ down-core resolution. Median probability age estimates were used to identify the depth intervals corresponding to European settlement (100 calibrated years before present; cal. yr BP) within each core (Electronic supplementary material; ESM Datasheet S1). Compositional comparisons between assemblages pre- and postdating European settlement (age) were made by a two-way PERMANOVA, with reef and age as factors. The analysis was performed in PAST (Hammer et al. 2001) using 9999 permutations and Bray-Curtis measures of dissimilarity. To remove any interaction associated with water depth, only depth intervals within which both temporal periods were represented were included in the analysis (ESM Table S1).

\section{Results}

\section{Sampling evaluation and palaeoecological inventory}

Taxonomic analysis of recovered coral materials identified 59 species of Scleractinia, from 29 genera (ESM Table S2). Sample-based rarefaction confirmed that sampling completeness was achieved across the PSRC and approached saturation for each reef (Fig. 3). The sampling strategy therefore provided a representative record of coral community development and change during vertical reef growth towards sea level across the PSRC.

The generic richness of the palaeoecological inventories across the PSRC ranged from 20 (OPS) to 24 (OPS-A). The dominant genera (by mass) contributing to the reef framework across the PSRC (Fig. 4; Table 2) were Acropora (mainly arborescent species, e.g. A. muricata and $A$. pulchra), Montipora (mainly platy species, e.g. M. aequituberculata), and Turbinaria (mainly T. mesenterina). Subsidiary, but volumetrically important, contributions were also made by Cyphastrea serailia, Euphyllia sp., Favites spp., Galaxea fascicularis, Goniopora sp., Hydnophora microconos, and Porites sp. (Fig. 4; Table 2). Although the palaeoecological assemblages across the PSRC included common taxa (Fig. 4), composition varied significantly among reefs $(p<0.001$; Table $3 a)$. Inter-reef dissimilarities, identified by SIMPER (Table 4), ranged from $37.7 \%$ (between OPS-A and OPS-B) to $51.3 \%$ (between OPS and OPS-D). Eight genera were identified as contributing most to the observed inter-reef differences (Table 4). Of these, Acropora, Montipora, and Turbinaria accounted for the majority of the observed inter-reef 

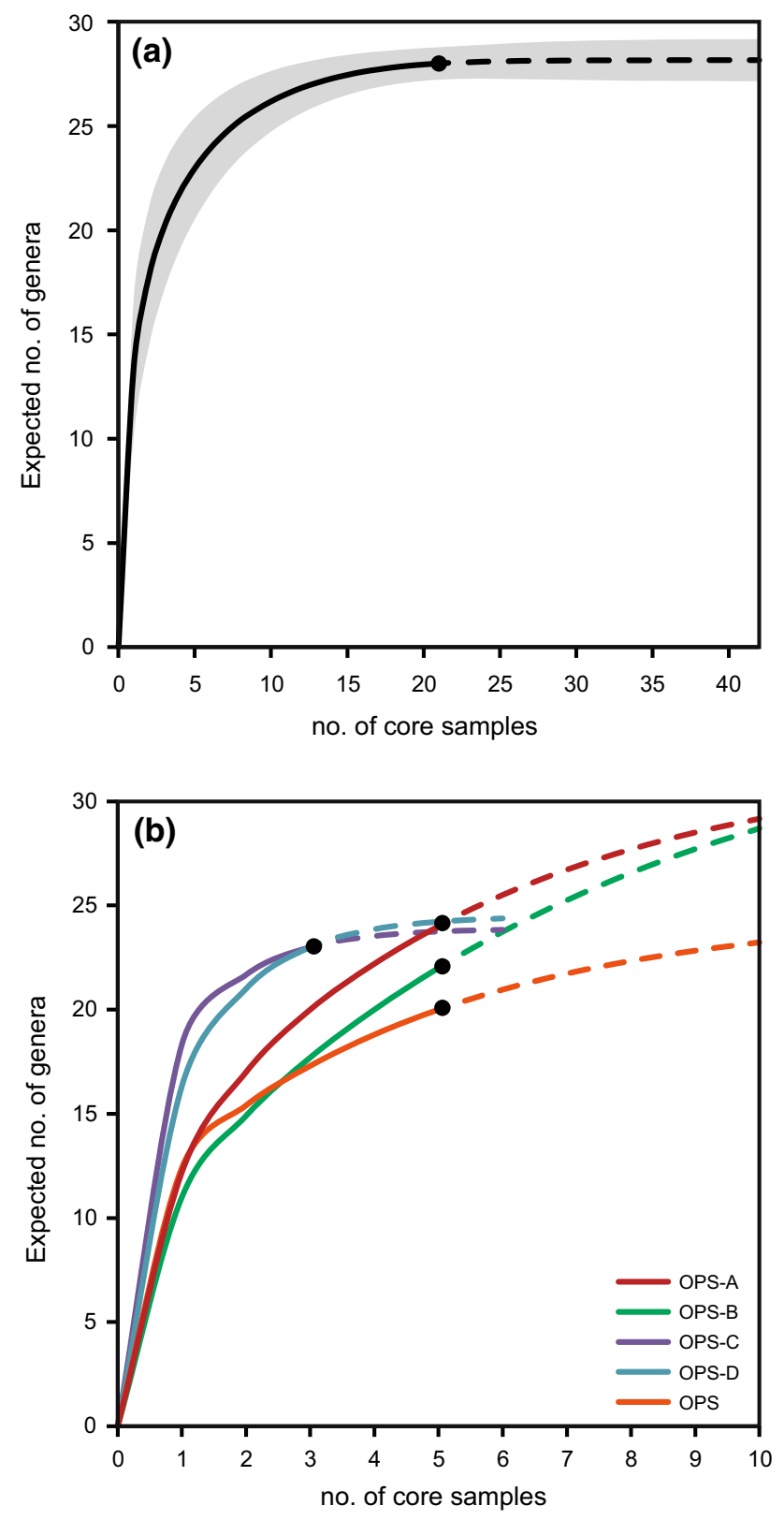

Fig. 3 Sample-based rarefaction curves generated for a the Paluma Shoals reef complex (PSRC); shading represents 95\% confidence intervals; and $\mathbf{b}$ the constituent reefs of the PSRC. Sample reference numbers are indicated by solid circles, rarefaction curves by solid lines, and extrapolation curves by dashed lines

differences, cumulatively accounting for an average dissimilarity of $41.4 \%$.

\section{Coral assemblage stratification}

There was no significant difference in coral assemblage composition between intervals pre- and post-dating European settlement ( $p=0.106$; Table 3b). Furthermore, tests remained insignificant when performed on both absolute mass and untransformed data. In contrast, coral assemblage composition varied significantly with water depth $(p<0.001$; Table $3 \mathrm{a})$. There was no significant interaction between reef and depth factors ( $p=0.191$; Table 3a). Pairwise post hoc tests divided coral assemblages into two significantly different groups between 0.8 and 4 m below LAT (ESM Table S3).

The first group represents a 'shallow' assemblage, occurring at depths of less than $\sim 1.6 \mathrm{~m}$ below LAT. This assemblage (Fig. 5a) is characterised by high abundances of Acropora ( $48.6 \pm 4.7 \%$, mean $\pm \mathrm{SE}$ ) and Montipora $(32.3 \pm 3.8 \%)$, with lesser contributions to the overall assemblage composition made by Turbinaria $(7.9 \pm 2.6 \%)$ and Porites $(5.9 \pm 2.7 \%)$. The second group occurs at depths greater than $\sim 1.6 \mathrm{~m}$ below LAT and represents a 'deep' assemblage (Fig. 5b). Differences between the identified 'deep' and 'shallow' assemblages are largely driven by the contribution of 'other' coral taxa (excluding Acropora, Montipora, Turbinaria, and Porites) to the overall assemblage composition. Collectively, 'other' taxa contributed $25.8 \pm 2.8 \%$ to the composition of the 'deep' assemblage, with key contributions to the group made by Euphyllia, Galaxea, and Goniopora (Fig. 5b). Within the 'shallow' assemblage, 'other' taxa accounted for only $5.3 \pm 2.0 \%$ of the overall assemblage composition, with Cyphastrea and Fungia contributing most to the group (Fig. 5a). The abundance of Montipora is notably lower within the 'deep' assemblage $(15.5 \pm 1.7 \%)$. Contributions by Acropora $(46.1 \pm 2.9 \%)$ and Turbinaria $(11.0 \pm 1.6 \%)$ to the overall composition of the 'deep' assemblage were similar to that of the 'shallow' assemblage (Fig. 5).

\section{Coral responses to water depth}

Water depth was identified as the key driver of assemblage compositional change and thus the key environmental factor from which to generate response curves. GAMs were fitted to the genera for which there were sufficient observations (Fig. 6). All models were significant at $p<0.001$ (Table 5) and show coral genera to display four main distributional types along the water depth gradient.

The first type consists of Acropora and Porites. In general, both genera display a positively skewed uni-modal distribution with optimum abundances occurring at depths of $\sim 1$ and $2 \mathrm{~m}$ below LAT, respectively. The second distributional type is that of a monotonic decrease in abundance with water depth and is entirely represented by Montipora. Abundances of Montipora are highest above LAT, where it replaces Acropora as the most abundant genus. The third distribution type is represented by Galaxea and Turbinaria which both exhibit trends of increasing abundance with water depth. This trend is most prominent at depths $>3.2 \mathrm{~m}$ below LAT. With the exception of depths deeper than $\sim 5 \mathrm{~m}$ below LAT, Turbinaria is the more abundant of the two genera and is the 
Fig. 4 Palaeoecological assemblage records of the five reefs cored within the Paluma Shoals reef complex. The average relative mass abundance of the major coral genera (Acropora, Montipora, and Turbinaria) is presented for each reef. All remaining taxa are grouped as 'Other' for presentation purposes. The main taxa $(>50 \%)$ contributing most to the 'Other' group are listed, respectively, in rank order, with their cumulative per cent contribution provided in brackets. Average basal radiocarbon ages (calibrated yr before present; cal. yr BP) and elevations of the European settlement $1850 \mathrm{AD}$ threshold (dashed line) are presented for each reef. All presented depths have been uncompacted and elevations corrected to lowest astronomical tide (LAT)

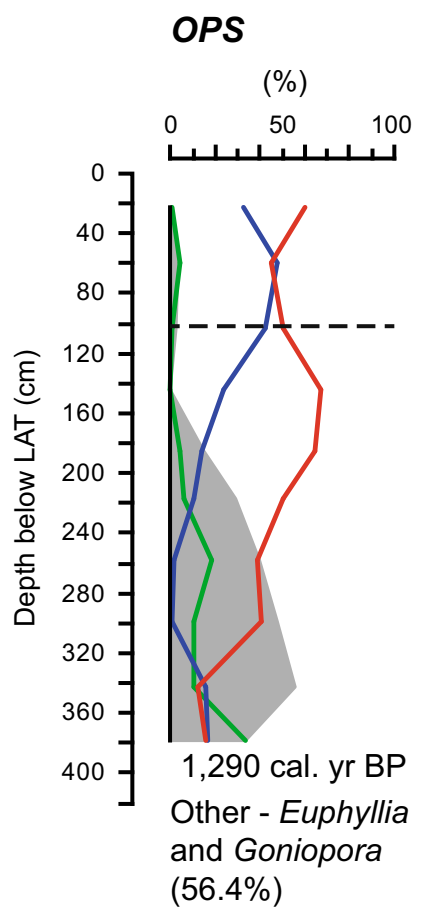

OPS-A

(\%)
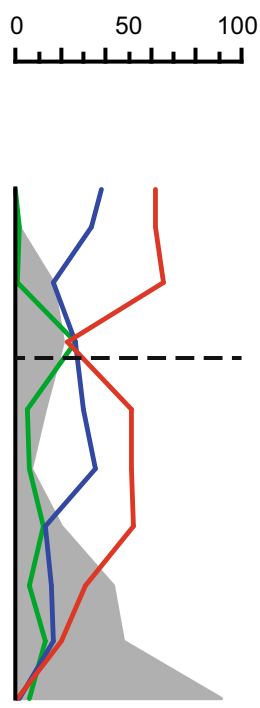

774 cal. yr BP

Other - Galaxea, Favites, Platygyra and Euphyllia $(60.8 \%)$

\section{OPS-C}

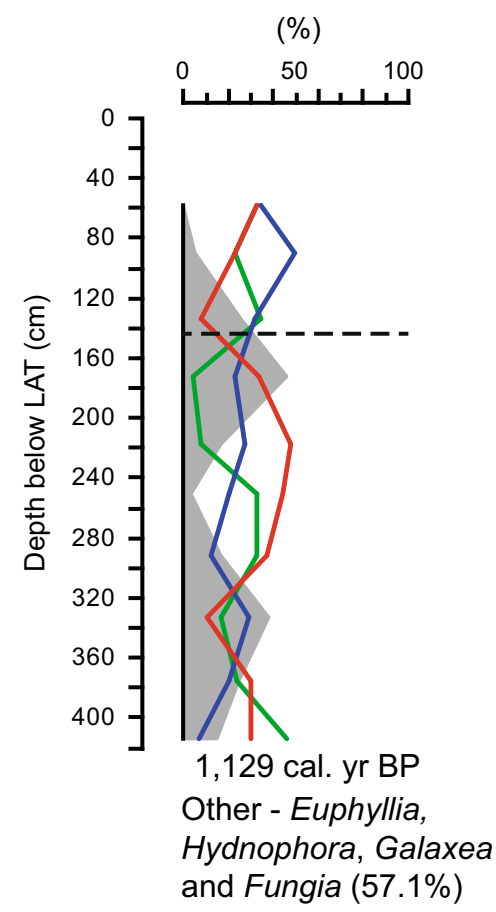

\section{OPS-D}
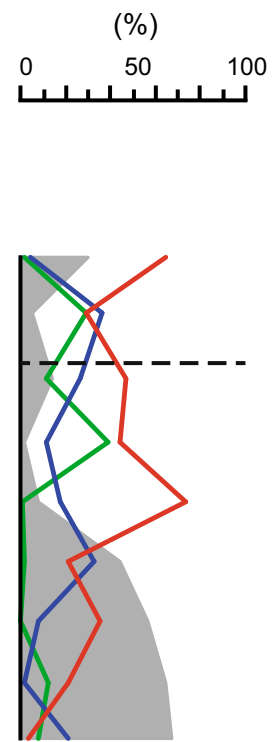

1,725 cal. yr BP

Other - Euphyllia

and Pachyseris

$(51.7 \%)$

\section{OPS-B}
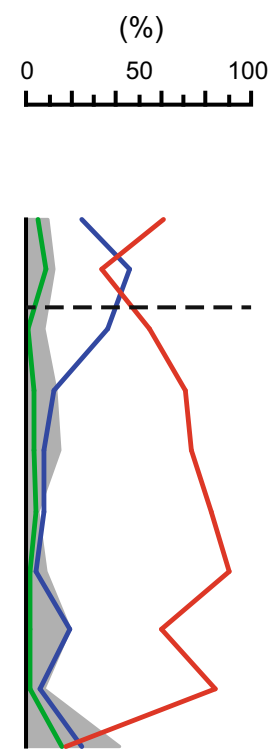

1,716 cal. yr BP

Other - Porites, Cyphastrea, Hydnophora, Psammocora and Platygyra (51.6\%)

\section{Stratigraphic key}

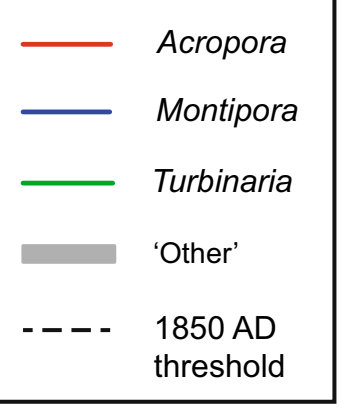

dominant genus at depths $>4$ m below LAT. Turbinaria also remains a major component of shallower assemblages, but at lower abundances. A negatively skewed uni-modal curve is the final distributional type and is represented by Euphyllia and Goniopora. In general, these taxa are most abundant at depths deeper than $\sim 3$ m below LAT. 
Table 3 Results of PERMANOVA using coral assemblage data with the factors (a) reef and depth; and (b) age (relative to European settlement) and reef

\begin{tabular}{lccccc}
\hline Source & $d f$ & SS & MS & Pseudo- $F$ & $p$ \\
\hline (a) Two-way PERMANOVA, reef, and depth & & & \\
Reef & 4 & 1.631 & 0.408 & 3.633 & 0.0001 \\
Depth & 7 & 1.826 & 0.261 & 2.324 & 0.0001 \\
Interaction & 28 & 1.872 & 0.067 & 0.596 & 0.1911 \\
Residual & 126 & 14.137 & 0.112 & & \\
Total & 165 & 19.465 & & & \\
(b) Two-way & PERMANOVA, pre-/post-European settlement (age), and reef & \\
Age & 1 & 0.097 & 0.097 & 1.286 & 0.1057 \\
Reef & 4 & 0.741 & 0.185 & 2.463 & 0.0001 \\
Interaction & 4 & -0.792 & -0.198 & -2.634 & \\
Residual & 49 & 3.684 & 0.075 & & \\
Total & 58 & 3.729 & & & \\
\end{tabular}

\begin{tabular}{|c|c|c|c|c|c|}
\hline Reef & OPS & OPS-A & OPS-B & OPS-C & OPS-D \\
\hline OPS & - & 48.1 & 46.8 & 48.8 & 51.3 \\
\hline OPS-A & $\begin{array}{l}\text { Montipora }(14.8) \\
\text { Turbinaria }(14.3) \\
\text { Acropora }(12.6) \\
\text { Euphyllia }(10.3) \\
\text { Cyphastrea }(8.5)\end{array}$ & - & 37.7 & 39.8 & 45.4 \\
\hline OPS-B & $\begin{array}{l}\text { Montipora }(15.4) \\
\text { Acropora }(14.7) \\
\text { Turbinaria }(14.1) \\
\text { Euphyllia }(9.7) \\
\text { Cyphastrea }(9.4)\end{array}$ & $\begin{array}{l}\text { Turbinaria }(15.8) \\
\text { Montipora }(14.2) \\
\text { Acropora }(10.6) \\
\text { Cyphastrea }(8.7) \\
\text { Porites }(8.7)\end{array}$ & - & 40.1 & 44.6 \\
\hline OPS-C & $\begin{array}{l}\text { Turbinaria }(16.9) \\
\text { Montipora }(14.2) \\
\text { Acropora }(12.8) \\
\text { Euphyllia }(10.2) \\
\text { Cyphastrea }(7.7)\end{array}$ & $\begin{array}{l}\text { Turbinaria }(17.1) \\
\text { Montipora }(11.3) \\
\text { Acropora }(10.4) \\
\text { Porites }(8.8) \\
\text { Euphyllia }(8.4)\end{array}$ & $\begin{array}{l}\text { Turbinaria }(19.4) \\
\text { Acropora }(13.9) \\
\text { Montipora }(12.9) \\
\text { Porites }(10.0) \\
\text { Hydnophora }(7.4)\end{array}$ & - & 45.2 \\
\hline OPS-D & $\begin{array}{l}\text { Turbinaria }(14.2) \\
\text { Acropora }(14.0) \\
\text { Montipora }(13.2) \\
\text { Euphyllia }(12.9) \\
\text { Galaxea }(9.2)\end{array}$ & $\begin{array}{l}\text { Turbinaria }(14.6) \\
\text { Montipora }(11.6) \\
\text { Euphyllia }(11.6) \\
\text { Acropora }(11.4) \\
\text { Galaxea }(8.9)\end{array}$ & $\begin{array}{l}\text { Turbinaria }(14.7) \\
\text { Acropora }(13.5) \\
\text { Montipora }(11.7) \\
\text { Euphyllia }(11.2) \\
\text { Porites }(8.2)\end{array}$ & $\begin{array}{l}\text { Turbinaria }(16.3) \\
\text { Acropora }(11.7) \\
\text { Euphyllia }(11.7) \\
\text { Montipora }(11.3) \\
\text { Porites }(8.5)\end{array}$ & - \\
\hline
\end{tabular}

Average between-reef dissimilarity (\%) is presented in bold with the five coral genera contributing most to the dissimilarity listed below the diagonal. The contribution (\%) to the total dissimilarity of each taxon is provided in brackets

\section{Discussion}

\section{Fossil records as archives of past coral assemblage composition}

Fossil coral assemblages are composed of materials originating from life assemblages mixed with those from co-occurring and surrounding death assemblages and are therefore considered to be representative of multiple populations (Edinger et al. 2001; Pandolfi 2002). The reliability with which palaeoecological records can be used to reconstruct the original composition of past coral communities is therefore dependent on the degree to which the fossil assemblage has been mixed over time (Pandolfi and Minchin 1995; Pandolfi 2002). Despite this limitation, a number of studies have shown that fossil coral assemblages provide a 
(a)

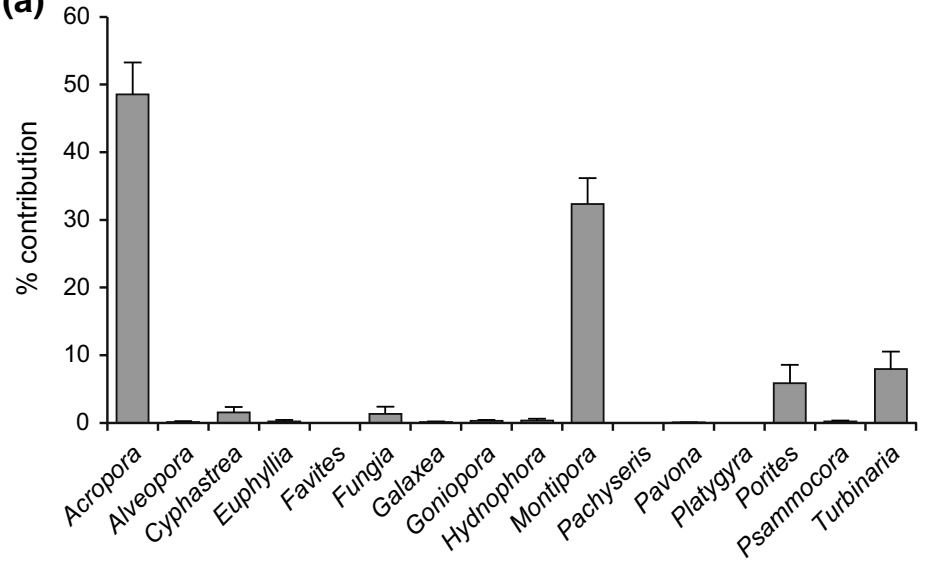

(b)

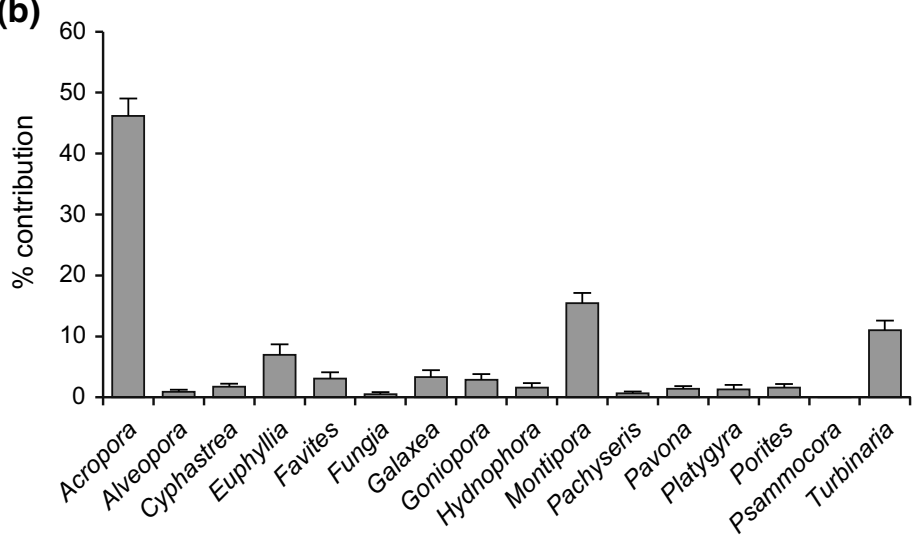

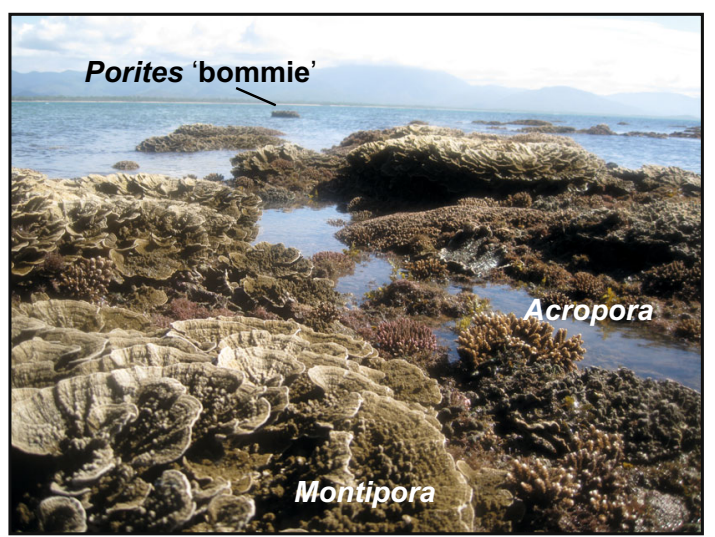

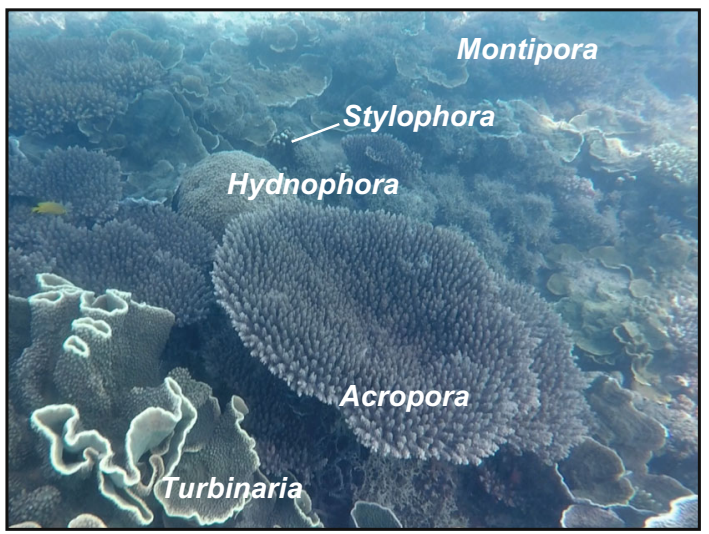

Fig. 5 Average relative contribution of coral genera to the overall assemblage composition of the identified: a 'shallow' assemblage ( $<1.6 \mathrm{~m}$ below lowest astronomical tide; LAT) and b 'deep' assemblage ( $>1.6 \mathrm{~m}$ below LAT). Error bars represent standard error (SE).

good measure of the overall composition of assemblages over timescales relevant to coral reef development and growth, especially where mixing can be inferred to be minimal (Pandolfi 1999; Edinger et al. 2001; Roche et al. 2011).

In this context, the degree to which a fossil assemblage reflects the composition of the original life assemblage is usually highest within low-energy environments (e.g. lagoonal and nearshore settings), where the potential for reworking and transportation is lowest (Scoffin 1992; Pandolfi and Minchin 1995; Edinger et al. 2001). Within the PSRC, limited reworking and transportation of coral materials can be inferred from: (1) the overall preservation of the coral material captured within the recovered cores (ESM Figs. S1-S6), and (2) the persistence of mud-rich terrigenous sediments throughout the entire reef sequence captured in the recovered cores (ESM Video S1). Given these sedimentary and taphonomic signatures, and the
Representative photographs of analogous modern assemblages within the Paluma Shoals reef complex are presented alongside the corresponding graph

effectiveness of the employed sampling strategy as inferred from the sample-based rarefaction analysis (Fig. 3), we are confident that the records presented in this study provide a reliable history of past coral community composition and change within the PSRC.

\section{Coral assemblages of the Paluma Shoals reef complex}

A total of 59 species (ESM Table S2) were identified from the palaeoecological inventory of the PSRC, $95 \%$ of which have previously been observed on the inner shelf of the GBR (Sweatman et al. 2007; OBIS 2015). To the best of our knowledge, Heterocyathus aequicostatus and Montipora effusa have not been previously recorded on the GBR inner shelf, though their distributional ranges are considered to include the zone (OBIS 2015). The richness 


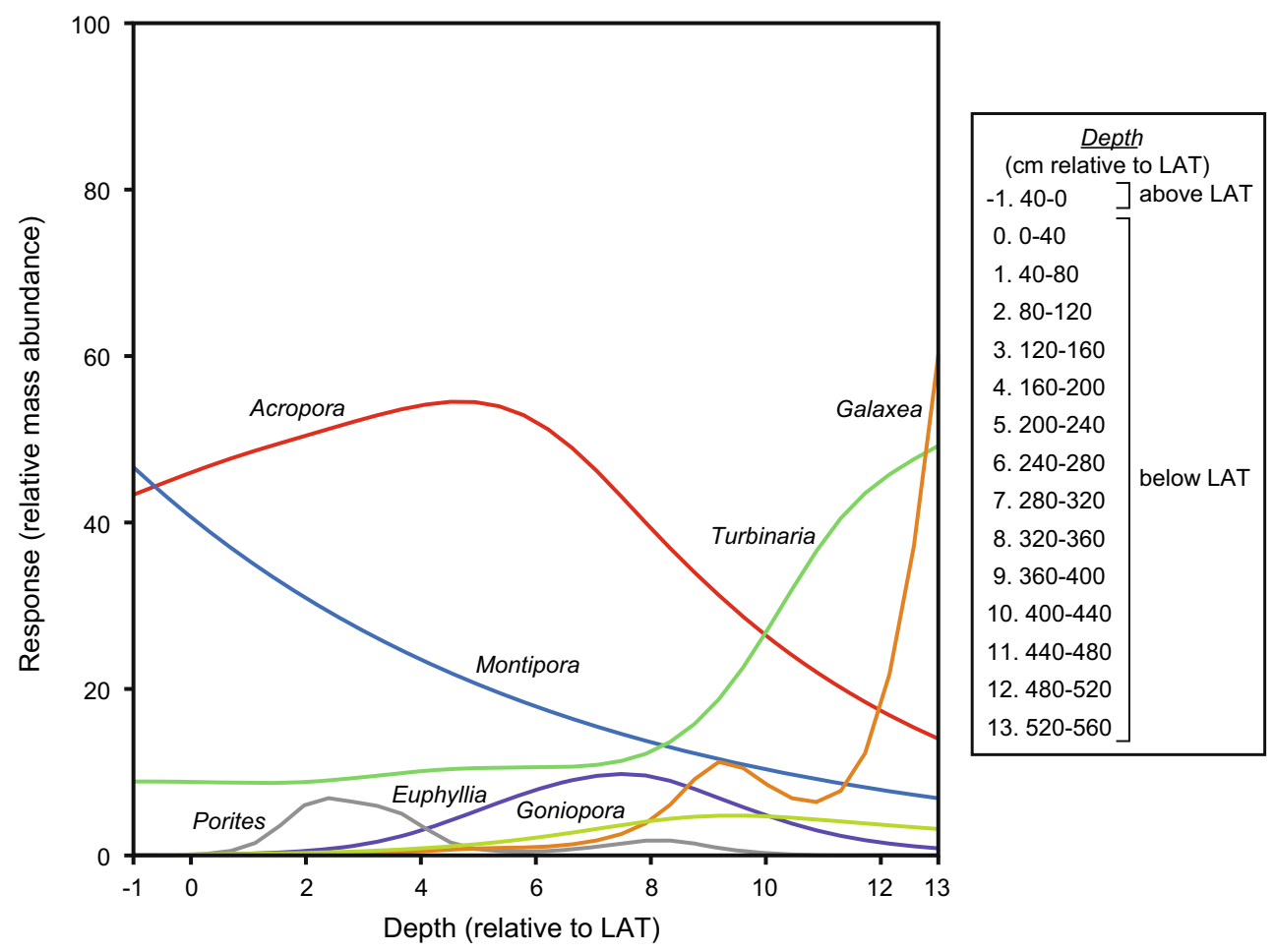

Fig. 6 The response (relative mass abundance) of coral genera to water depth (relative to lowest astronomical tide), modelled by generalised additive modelling. Summary statistics are provided in Table 5

Table 5 Summary statistics from generalised additive modelling of the response (relative mass abundance) of coral genera to water depth (relative to lowest astronomical tide)

\begin{tabular}{llllllll}
\hline Response & Acropora & Euphyllia & Galaxea & Goniopora & Montipora & Porites & Turbinaria \\
\hline Selected model & $*_{\mathrm{s}}(\mathrm{X}, 3)$ & $*_{\mathrm{s}}(\mathrm{X}, 3)$ & $*_{\mathrm{s}}(\mathrm{X}, 6)$ & $*_{\mathrm{s}}(\mathrm{X}, 2)$ & $*_{\mathrm{s}}(\mathrm{X}, 1)$ & $*_{\mathrm{s}}(\mathrm{X}, 6)$ & $*_{\mathrm{s}}(\mathrm{X}, 4)$ \\
Null model deviance & 6120.24 & 4574.88 & 3708.05 & 2442.14 & 5516.55 & 2506.98 & 6282.77 \\
Fitted model deviance & 5469.31 & 3791.17 & 2260.09 & 2027.55 & 4658.37 & 1972.54 \\
$F$ & 9.78 & 7.44 & 10.56 & 9.13 & 34.33 & 4.18 \\
$p$ & $<0.001$ & $<0.001$ & $<0.001$ & $<0.001$ & $<0.001$ & $<0.001$ \\
\hline
\end{tabular}

*s Denotes the selected model (X, $i$ ), where $i$ refers to the degree of complexity (expressed as degrees of freedom). Models with the highest parsimony were selected using the Akaike information criterion

of genera on the PSRC is higher than previously reported from core records recovered from the landward and more geomorphologically mature reefs of Paluma Shoals (north and south shoal; Perry et al. 2008), but is similar to that reported for other nearshore reefs on the central GBR (e.g. Roche et al. 2011; Ryan et al. 2016). We also note that $90 \%$ of the genera identified in this study are present within the contemporary coral communities of the PSRC (Morgan et al. 2016a). Furthermore, the generic richness of the palaeoecological inventory is comparable to the contemporary nearshore coral communities of Middle Reef in Cleveland Bay, approximately $30 \mathrm{~km}$ to the south (Browne et al. 2010).
The palaeoecological assemblages of the PSRC are representative of inner-shelf reef communities across the central GBR (DeVantier et al. 2006), which are characterised by mixed assemblages of acroporids (Montipora, and locally abundant Acropora; Done 1982), dendrophyllids (Turbinaria), euphylliids (Euphyllia and Galaxea), and poritids (Goniopora and Porites). The composition of inner-shelf coral communities distinguishes them from those associated with mid- and outer-shelf reefs, which are predominantly characterised by assemblages of Acropora (Done 1982; DeVantier et al. 2006).

In the PSRC, Acropora was one of the most dominant taxa within palaeoecological assemblages (Fig. 4; 
Table 2). This is consistent with recent surveys of contemporary coral communities that found Acropora to account for up to $\sim 30 \%$ of the average live coral cover on the PSRC composite reefs (Morgan et al. 2016a). As the analyses in this study were at the genus level, spatial differences and temporal changes in assemblage composition at the species level cannot be explicitly inferred. However, species inventory comparisons suggest that the Acropora assemblages of the PSRC (ESM Table S2) are composed of different species (notably arborescent species, e.g. $A$. muricata and A. pulchra) from those of the central GBR mid- and outer-shelf reefs, which are characterised by assemblages of $A$. hyacinthus/valenciennes (formerly $A$. splendida) and $A$. humilis/Isopora palifera (formerly $A$. palifera), respectively (Done 1982; DeVantier et al. 2006).

\section{Vertical trends in nearshore coral distribution}

Recent surveys of the contemporary coral communities of the PSRC have shown that coral taxa exhibit clear depth stratification (Morgan et al. 2016a). Specifically, benthic surveys found shallow ( $<1.5 \mathrm{~m}$ below LAT) coral assemblages to be characterised by Acropora and Montipora, while Turbinaria and taxa with sub-massive growth forms (e.g. Galaxea and Goniopora) were associated with deeper assemblages. These observed trends are remarkably well preserved within the palaeoecological records of the PSRC (Figs. 5, 6). This finding therefore, provides compelling evidence for the argument that nearshore coral communities, and the associated controls of community development, have remained largely unchanged throughout the growth history of the PSRC.

Similar patterns in the vertical distribution of coral taxa have also been reported for contemporary coral communities across the central GBR continental shelf. These patterns have been attributed to intrinsic variations in hydrodynamic energy and, by association, changes in light availability and sedimentation (Yentsch et al. 2002; Wolanski et al. 2005), corresponding to shallowing conditions during vertical reef development towards sea level. Specifically, the palaeoecological record of the PSRC demonstrates the preference of Euphyllia, Galaxea, Goniopora, and Turbinaria for deeper environments (approx. $>3 \mathrm{~m}$ below LAT; Fig. 6). These genera are likely representative of the main coral taxa associated with the early incipient stages of reef development within the PSRC. Available radiocarbon dates (Perry et al. 2013; Morgan et al. 2016b) suggest that reef initiation within the PSRC occurred between $\sim 2000$ and 700 cal. yr BP (Fig. 2). Although the precise nature of past regional sea-level dynamics is still debatable, existing sea-level curves suggest that reef initiation within the PSRC reef occurred when palaeowater depths were no greater than $1 \mathrm{~m}$ above present-day elevations (i.e. at depths between $\sim 4$ and $5 \mathrm{~m}$ below present LAT; Lewis et al. 2013, 2015). These reported initiation depths are comparable to recent estimates of maximum photic depths within the coastal zone of the Burdekin region of the GBR, suggesting that benthic light availability is a key environmental control for the initiation of reef development within turbid nearshore environments (Fabricius et al. 2016; Morgan et al. 2016b).

Subsequent shallower stages of vertical reef development within the PSRC are dominated by Acropora and Montipora (Fig. 6). Due to their ability to settle in dense patches and grow rapidly, these taxa are considered to be opportunistic (Done et al. 2007). Interestingly, the palaeoecological record of the PSRC indicates a decline in the prevalence of Acropora as water depth shallows beyond $\sim 2 \mathrm{~m}$ below LAT, with Montipora becoming the dominant genus following attainment of LAT (Fig. 6). This transition also corresponds with a decline in generic richness between the identified 'shallow' and 'deep' assemblages (Fig. 5) and is consistent with reported trends of decreasing taxonomic richness with progressive shallowing along the water depth gradient (DeVantier et al. 2006). This shallowing signal is interpreted as a response to increased wave exposure under vertical reef development towards sea level (Done et al. 2007; Roberts et al. 2015; Morgan et al. 2016a) and highlights the importance of considering geomorphological maturity when determining the ecological status of a reef (Perry and Smithers 2011). Under further vertical growth and lateral reef flat development, over time we anticipate that the reef-top communities of the PSRC will transition towards an aerially exposed intertidal coral community dominated by the thermally and high irradiance-tolerant species, Coelastrea aspera (formerly Goniastrea aspera; Brown et al. 2002; Huang et al. 2014). Such communities are characteristic of contemporary sea-level-constrained nearshore reef flats elsewhere on the central GBR (e.g. Roche et al. 2011; Browne et al. 2010; Palmer et al. 2010).

\section{Nearshore reef resilience}

Several studies have argued that the observed robust nature of nearshore coral communities is a function of the naturally 'marginal' environments in which they occur (Larcombe and Woolfe 1999a; Perry et al. 2008, 2009). Under this premise, it is proposed that the naturally high background sedimentary environment occupied by nearshore coral reefs acts to buffer the magnitude of water-quality change to which the corals are exposed (Larcombe and Woolfe 1999a; Orpin and Ridd 2012). Our records found no discernible evidence of generic compositional change within nearshore coral assemblages relative to European settlement. Instead, this study demonstrates the long-term 
persistence of coral communities and their associated taxa within nearshore environments on the central GBR. These results are consistent with those of other palaeoecological studies derived from both coral (e.g. Perry et al. 2008, 2009; Ryan et al. 2016) and foraminiferal records (e.g. Reymond et al. 2013) from other inner-shelf reefs on the central GBR. Collectively, these studies demonstrate the important role of palaeoecological records for the assessment and contextualisation of both ecological and environmental change on coral reefs.

Furthermore, high rates of sedimentation and chronic low light conditions as a result of light attenuation by suspended sediments can be inferred to have persisted throughout the entire growth history of the PSRC (ESM Video S1). Undoubtedly, these environmental conditions have encouraged and promoted the development of coral communities characterised by taxa which are pre-adapted to conditions of high turbidity within the most nearshore areas of the central GBR (see Browne et al. 2012a and references therein). Indeed, several genera characteristic of the PSRC and other inner-shelf reef communities are known to be able to cope with low light availability and/or high rates of sedimentation (see Anthony and Fabricius 2000; Anthony et al. 2005; Houlbrèque and Ferrier-Pagès 2009; Browne et al. 2012a). Typical adaptive mechanisms include the short-term coping strategies of heterotrophic feeding (e.g. Coelastrea), an increased capacity for sediment removal (e.g. Galaxea, Goniopora, Porites, Platygyra), and the longer-term strategy of morphological plasticity (e.g. Turbinaria). The adaptive potential of certain coral taxa to the sedimentary conditions of the GBR nearshore setting is further demonstrated by the measured growth rates of the common nearshore species A. muricata and $M$. aequituberculata, which are comparable to those of their clear-water counterparts (Browne 2012).

\section{Further considerations}

This study supports the premise that water-quality decline following European settlement has not yet impacted the most nearshore reefs of the central GBR (Larcombe and Woolfe 1999a; Orpin and Ridd 2012). The palaeoecological records presented in this study therefore represent important ecological baselines that can be used for monitoring and assessing future ecological change on nearshore coral reefs in the region. Our findings demonstrate the apparently robust nature of nearshore reefs and suggest that their associated coral communities may be more resilient to changes in water quality than those of inshore reefs. To this end, areas where coral communities are likely to be more susceptible to reduced water quality include locations where (1) the local natural sedimentary background conditions are less extreme, such as inshore coral reefs towards the seaward margin of the inshore sediment prism (e.g. Pelorus Island; Roff et al. 2013), and (2) the presence of gyres may potentially restrict flushing times of coastal waters (Clark et al. 2016). Additional palaeoecological coral assemblage records, developed for nearshore coral reefs across the gradient of sediment influence and spectrum of reef geomorphic development, are required to further test the spatial consistencies of the trends reported in this study.

Acknowledgements We thank the crew of the R.V. James Kirby for their support and assistance during fieldwork, and J. Daniell for his assistance with core recovery. Field research was supported by a Natural Environment Research Council (NERC) Grant (NE/J023329/ 1) to CTP and SGS, and radiocarbon dating of the core samples through NERC Radiocarbon Dating Allocations 1727.1013 and 1838.1014 to CTP and KMM. Fieldwork was conducted under GBRMPA research permit G13/36076.1. We thank two anonymous reviewers for their helpful comments and suggestions that greatly improved this manuscript

Open Access This article is distributed under the terms of the Creative Commons Attribution 4.0 International License (http://creativecommons. org/licenses/by/4.0/), which permits unrestricted use, distribution, and reproduction in any medium, provided you give appropriate credit to the original author(s) and the source, provide a link to the Creative Commons license, and indicate if changes were made.

\section{References}

Anderson MJ (2001) A new method for non-parametric multivariate analysis of variance. Austral Ecol 26:32-46

Anthony KRN, Fabricius KE (2000) Shifting roles of heterotrophy and autotrophy in coral energetics under varying turbidity. J Exp Mar Bio Ecol 252:221-253

Anthony KRN, Hoogenboom MO, Connolly SR (2005) Adaptive variation in coral geometry and the optimization of internal colony light climates. Funct Ecol 19:17-26

Beaman RJ (2010) Project 3DGBR: a high-resolution depth model for the Great Barrier Reef and Coral Sea. Marine and Tropical Sciences Research Facility (MTSRF) Project 2.5i.1a Final Report, MTSRF, Cairns, Australia

Bennett KD (1994) Confidence intervals for age estimates and deposition times in late-Quaternary sediment sequences. Holocene 4:337-348

Blaauw M, Christen A (2011) Flexible paleoclimate age-depth model using an autoregressive gamma process. Bayesian Anal 6:457-474

Blaauw M, Heegaard E (2012) Estimation of age-depth relationships. In: Birks HJB, Lotter AF, Juggins S, Smol JP (eds) Tracking environmental change using lake sediments, volume 5: data handling and numerical techniques. Springer, Netherlands, pp 379-413

Bonelli JR, Brett CE, Miller AI, Bennington JB (2006) Testing for faunal stability across a regional biotic transition: quantifying stasis and variation among recurring coral-rich biofacies in the Middle Devonian Appalachian Basin. Paleobiology 32:20-37

Brodie JE, Kroon FJ, Schaffelke B, Wolanski EC, Lewis SE, Devlin MJ, Bohnet IC, Bainbridge ZT, Waterhouse J, Davies AM (2012) Terrestrial pollutant runoff to the Great Barrier Reef: an update of issues, priorities and management responses. Mar Pollut Bull 65:81-100 
Brown BE, Downs CA, Dunne RP, Gibb SW (2002) Exploring the basis of thermotolerance in the reef coral Goniastrea aspera. Mar Ecol Prog Ser 242:119-129

Browne NK (2012) Spatial and temporal variations in coral growth on an inshore turbid reef subjected to multiple disturbances. Mar Environ Res 77:71-83

Browne NK, Smithers SG, Perry CT (2010) Geomorphology and community structure of Middle Reef, central Great Barrier Reef, Australia: an inner-shelf turbid zone reef subject to episodic mortality events. Coral Reefs 29:683-689

Browne NK, Smithers SG, Perry CT (2012a) Coral reefs of the turbid inner shelf of the Great Barrier Reef, Australia: an environmental and geomorphic perspective on their occurrence, composition and growth. Earth Sci Rev 115:1-20

Browne NK, Smithers SG, Perry CT (2012b) Spatial and temporal variations in turbidity on two inshore turbid reefs on the Great Barrier Reef, Australia. Coral Reefs 32:195-210

Browne NK, Smithers SG, Perry CT, Ridd PV (2012c) A field-based technique for measuring sediment flux on coral reefs: application to turbid reefs on the Great Barrier Reef. J Coast Res 28:1247-1262

Cairns SD, Parker SA (1992) Review of the recent Scleractinia (stony corals) of South Australia, Victoria and Tasmania. Records of the South Australian Museum monograph series number 3, South Australian Museum, Adelaide, pp 1-40

Clark TR, Leonard ND, Zhao J-X, Brodie J, McCook LJ, Wachenfeld DR, Nguyen AD, Markham HL, Pandolfi JM (2016) Historical photographs revisited: a case study for dating and characterizing recent loss of coral cover on the inshore Great Barrier Reef. Sci Rep 6:19285

Clarke KR (1993) Non-parametric multivariate analyses of changes in community structure. Australian Journal of Ecology 18:117-143

Clarke KR, Warwick RM (2001) Change in marine communities: an approach to statistical analysis and interpretation. PRIMER-E, Plymouth, UK

Colwell RK (2013) EstimateS: statistical estimation of species richness and shared species from samples, version 9.1.0. User's guide and application. University of Connecticut, USA. http:// purl.oclc.org/estimates

Colwell RK, Chao A, Gotelli NJ, Lin SY, Mao CX, Chazdon RL, Longino JT (2012) Models and estimators linking individualbased and sample-based rarefaction, extrapolation and comparison of assemblages. Journal of Plant Ecology 5:3-21

DeVantier LM, De'ath G, Turak E, Done TJ, Fabricius KE (2006) Species richness and community structure of reef-building corals on the nearshore Great Barrier Reef. Coral Reefs 25:329-340

Devlin MJ, Brodie J (2005) Terrestrial discharge into the Great Barrier Reef Lagoon: nutrient behaviour in coastal waters. Mar Pollut Bull 51:9-22

Done TJ (1982) Patterns in the distribution of coral communities across the central Great Barrier Reef. Coral Reefs 1:95-107

Done T, Turak E, Wakeford M, DeVantier L, McDonald A, Fisk D (2007) Decadal changes in turbid-water coral communities at Pandora Reef: loss of resilience or too soon to tell? Coral Reefs 26:789-805

Edinger EN, Pandolfi JM, Kelley RA (2001) Community structure of Quaternary coral reefs compared with recent life and death assemblages. Paleobiology 27:669-694

Erftemeijer PLA, Riegl B, Hoeksema BW, Todd PA (2012) Environmental impacts of dredging and other sediments on corals: a review. Mar Pollut Bull 64:1737-1765

Fabricius K, De'ath G, McCook L, Turak E, Williams D (2005) Changes in algal, coral and fish assemblages along water quality gradients on the inshore Great Barrier Reef. Mar Pollut Bull 51:384-398
Fabricius KE, Logan M, Weeks SJ, Lewis SE, Brodie J (2016) Changes in water clarity in response to river discharges on the Great Barrier Reef continental shelf: 2002-2013. Estuar Coast Shelf Sci 173:1-15

Hammer O, Harper DAT, Ryan PD (2001) PAST: paleontological statistics software package for education and data analysis. Palaeontologia Electronica 4:1-9

Houlbrèque F, Ferrier-Pagès C (2009) Heterotrophy in tropical scleractinian corals. Biol Rev Camb Philos Soc 84:1-17

Hopley D (1982) The geomorphology of the Great Barrier Reef: Quaternary development of coral reefs. John Wiley \& Sons, New York

Huang D, Benzoni F, Fukami H, Knowlton N, Smith ND, Budd AF (2014) Taxonomic classification of the reef coral families Merulinidae, Montastraeidae, and Diploastraeidae (Cnideria: Anthozoa: Scleractinia). Zool J Linn Soc 171:277-355

Jones R, Ricardo GF, Negri AP (2015) Effects of sediments on the reproductive cycle of corals. Mar Pollut Bull 100:13-33

Kroon FJ, Kuhnert PM, Henderson BL, Wilkinson SN, KinsetHenderson A, Abbott B, Brodie JE, Turner RDR (2012) River loads of suspended solids, nitrogen, phosphorus and herbicides delivered to the Great Barrier Reef lagoon. Mar Pollut Bull 65:167-181

Larcombe P, Woolfe KJ (1999a) Increased sediment supply to the Great Barrier Reef will not increase sediment accumulation at most coral reefs. Coral Reefs 18:163-169

Larcombe P, Woolfe KJ (1999b) Terrigenous sediments as influences upon Holocene nearshore coral reefs, central Great Barrier Reef, Australia. Australian Journal of Earth Sciences 46:141-154

Larcombe P, Costen A, Woolfe KJ (2001) The hydrodynamics and sedimentary setting of nearshore coral reefs, central Great Barrier Reef shelf, Australia: Paluma Shoals, a case study. Sedimentology 48:811-835

Legendre P, Birks HJB (2012) From classical to canonical ordination. In: Birks HJB, Lotter AF, Juggins S, Smol JP (eds) Tracking environmental change using lake sediments, vol 5., data handling and numerical techniquesSpringer, Netherlands, pp 201-248

Lepš J, Šmilauer P (2003) Multivariate analysis of ecological data using CANOCO. Cambridge University Press, Cambridge, UK

Lewis SE, Shields GA, Kamber BS, Lough JM (2007) A multi-trace element coral record of land-use changes in the Burdekin River catchment, NE Australia. Palaeogeogr Palaeoclimatol Palaeoecol 246:471-487

Lewis SE, Sloss CR, Murray-Wallace CV, Woodroffe CD, Smithers SG (2013) Post-glacial sea-level changes around the Australian margin: a review. Quat Sci Rev 74:115-138

Lewis SE, Wüst RAJ, Webster JM, Collins J, Wright SA, Jacobsen G (2015) Rapid relative sea-level fall along north-eastern Australia between 1200 and $800 \mathrm{cal}$. yr BP: an appraisal of the oyster evidence. Mar Geol 370:20-30

Morgan KM, Perry CT, Smithers SG, Johnson JA, Daniell JJ (2016a) Evidence of extensive reef development and high coral cover in nearshore environments: implications for understanding coral adaptation in turbid settings. Sci Rep 6:29616

Morgan KM, Perry CT, Smithers SG, Johnson JA, Gulliver P (2016b) Transitions in coral reef accretion rates linked to intrinsic ecological shifts on turbid-zone nearshore reefs. Geology 44:995-998

OBIS (2015) Ocean Biogeographic Information System. Intergovernmental Oceanographic Commission of UNESCO. http:// www.iobis.org

Orpin AR, Ridd PV (2012) Exposure of inshore corals to suspended sediments due to wave-resuspension and river plumes in the central Great Barrier Reef: a reappraisal. Cont Shelf Res 47:55-67 
Palmer SE, Perry CT, Smithers SG, Gulliver P (2010) Internal and accretionary history of a nearshore, turbid-zone coral reef: Paluma Shoals, central Great Barrier Reef, Australia. Mar Geol 276:14-29

Pandolfi JM (1999) Response of Pleistocene coral reefs to environmental change over long temporal scales. Am Zool 39:113-130

Pandolfi JM (2002) Coral community dynamics at multiple scales. Coral Reefs 21:13-23

Pandolfi JM, Minchin PR (1995) A comparison of taxonomic composition and diversity between reef coral life and death assemblages in Madang Lagoon, Papua New Guinea. Palaeogeogr Palaeoclimatol Palaeoecol 119:321-341

Parnell AC, Buck CE, Doan TK (2011) A review of statistical chronology models for high-resolution, proxy-based Holocene palaeoenvironmental reconstruction. Quat Sci Rev 30:2948-2960

Perry CT, Larcombe P (2003) Marginal and non-reef-building coral environments. Coral Reefs 22:427-432

Perry CT, Smithers SG (2011) Cycles of coral reef 'turn-on', rapid growth and 'turn-off' over the past 8500 years: a context for understanding modern ecological states and trajectories. Glob Chang Biol 17:76-86

Perry CT, Smithers SG, Johnson KG (2009) Long-term coral community records from Lugger Shoals on the terrigenous inner-shelf of the central Great Barrier Reef, Australia. Coral Reefs 28:941-948

Perry CT, Smithers SG, Gulliver P (2013) Rapid vertical accretion on a 'young' shore-detached turbid zone reef: Offshore Paluma Shoals, central Great Barrier Reef, Australia. Coral Reefs 32:1143-1148

Perry CT, Smithers SG, Gulliver P, Browne NK (2012) Evidence of very rapid reef accretion and reef growth under high turbidity and terrigenous sedimentation. Geology 40:719-722

Perry CT, Smithers SG, Palmer SE, Larcombe P, Johnson KG (2008) 1200 year paleoecological record of coral community development from the terrigenous inner shelf of the Great Barrier Reef. Geology 36:691-694

R Development Core Team (2014) R: a language and environment for statistical computing. R Foundation for Statistical Computing, Vienna, Austria

Reymond CE, Roff G, Chivas AR, Zhao J-X, Pandolfi JM (2013) Millennium-scale records of benthic foraminiferal communities from the central Great Barrier Reef reveal spatial differences and temporal consistency. Palaeogeogr Palaeoclimatol Palaeoecol 374:52-61

Roberts TE, Moloney JM, Sweatman HPA, Bridge TCL (2015) Benthic community composition on submerged reefs in the central Great Barrier Reef. Coral Reefs 34:569-580

Roche RC, Perry CT, Johnson KG, Sultana K, Smithers SG, Thompson AA (2011) Mid-Holocene coral community data as baselines for understanding contemporary reef ecological states. Palaeogeogr Palaeoclimatol Palaeoecol 299:159-167

Roff GR, Clark TR, Reymond CE, Zhao J-X, Feng Y, McCook LJ, Done TJ, Pandolfi JM (2013) Palaeoecological evidence of a historical collapse of corals at Pelorus Island, inshore Great Barrier Reef, following European settlement. Proc R Soc Lond B Biol Sci 280:20122100

Ryan EJ, Smithers SG, Lewis SE, Clark TR, Zhao J-X (2016) Chronostratigraphy of Bramston Reef reveals a long-term record of fringing reef growth under muddy conditions in the central Great Barrier Reef. Palaeogeogr Palaeoclimatol Palaeoecol 441:734-747

Santodomingo N, Renema W, Johnson KG (2016) Understanding the murky history of the Coral Triangle: Miocene corals and reef habitats in East Kalimantan (Indonesia). Coral Reefs 35:765-781

Skácelová O, Lepš J (2014) The relationship of diversity and biomass in phytoplankton communities weakens when accounting for species proportions. Hydrobiologia. 724:67-77

Scoffin TP (1992) Taphonomy of coral reefs: a review. Coral Reefs 11:57-77

Smithers S, Larcombe P (2003) Late Holocene initiation and growth of a nearshore turbid-zone coral reef: Paluma Shoals, central Great Barrier Reef, Australia. Coral Reefs 2:499-505

Sweatman H, Thompson A, Delean S, Davidson J, Neale S (2007) Status of near-shore reefs of the Great Barrier Reef 2004. CRC Reef Research Centre, Cairns, Australia

Ter Braak CJF, Šmilauer P (2002) CANOCO reference manual and CanoDraw for Windows user's guide: software for canonical community ordination (version 4.5). Microcomputer Power, New York

Veron JEN, Pichon M (1976) Scleractinia of eastern Australia, Part I. Families Thamnasteriidae, Astroceniidae and Pocillopporidae. Australian Institute of Marine Science Monograph Series, Australian Government Publishing Service, Canberra, 102 pp

Veron JEN, Pichon M (1980) Scleractinia of eastern Australia, Part III. Families Agariciidae, Siderastreidae, Fungiidae, Oculinidae, Merulinidae, Mussidae, Pectiniidae, Caryophylliidae, Dendrophylliidae. Australian Institute of Marine Science Monograph Series, Australian Government Publishing Service, Canberra, $422 \mathrm{pp}$

Veron JEN, Pichon M (1984) Scleractinia of Eastern Australia, Part IV. Family Poritidae. Australian Institute of Marine Science Monograph Series, Australian Government Publishing Service, Canberra, $159 \mathrm{pp}$

Wallace CC (1999) Staghorn corals of the world: a revision of the coral genus Acropora (Scleractinia; Astrocoeniina; Acroporidae) worldwide, with emphasis on morphology, phylogeny and biogeography. CSIRO publishing, Collingwood

Wolanski E, Fabricius K, Spagnol S, Brinkman R (2005) Fine sediment budget on an inner-shelf coral-fringed island, Great Barrier Reef of Australia. Estuar Coast Shelf Sci 65:153-158

Woolfe KJ, Larcombe P (1999) Terrigenous sedimentation and coral reef growth: a conceptual framework. Mar Geol 155:331-345

Yentsch CS, Yentsch CM, Cullen JJ, Lapointe B, Phinney DA, Yentsch SW (2002) Sunlight and water transparency: cornerstones in coral research. J Exp Mar Bio Ecol 268:171-183 